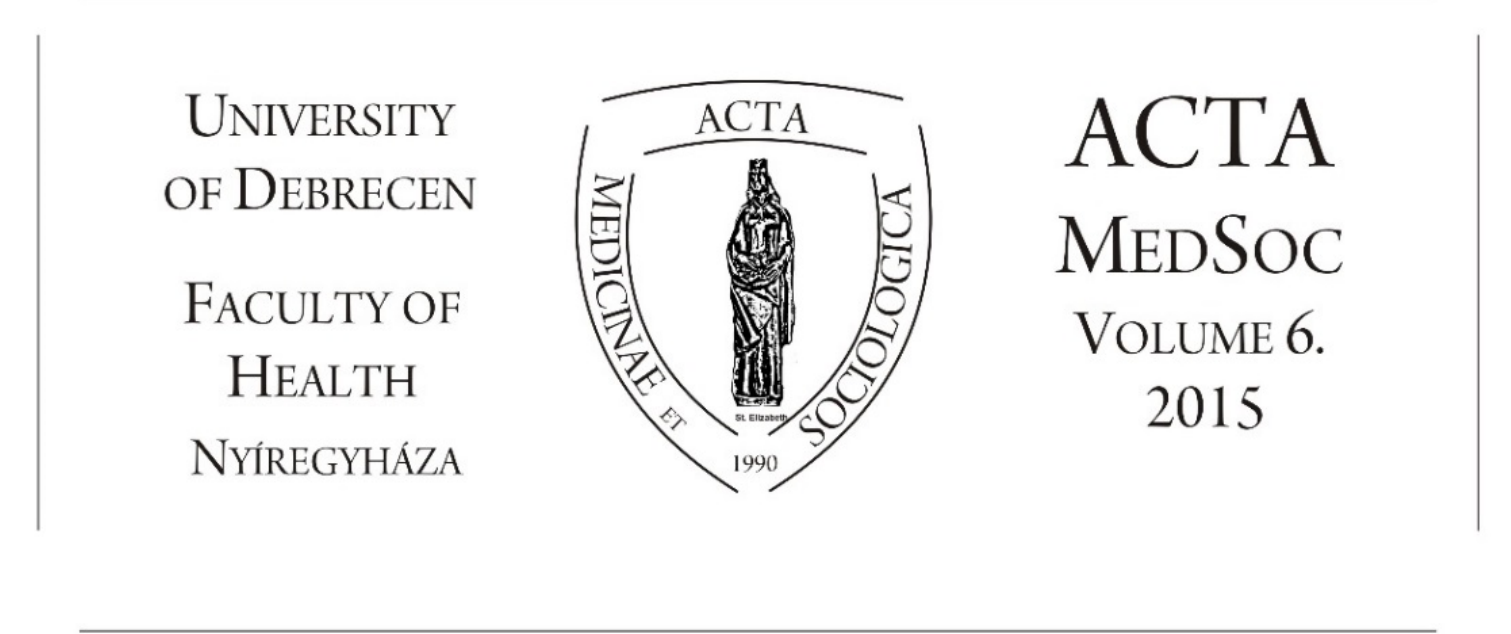

\title{
Az érzelmi jóllét mérése a Nyíregyházi járás településein
}

\author{
Szigeti Fruzsina - Fábián Gergely - Takács Péter \\ Debreceni Egyetem Egészségügyi Kar
}

\begin{abstract}
Very few Hungarian studies focus on measuring quality of life and the parameters of its emotional well-being. (Kékesi, 2007.) The recent quality of life research has been conducted by using the Oxford Happiness Questionnaire among the population of Nyíregyháza and the nearest settlements to try to compensate the lack of valid measures and studies.

This research tries to give a clear picture of happiness values and common opinions or responses to questions on the items of happiness.

Specific features can be seen in the development of happiness values: the older an age group is, the less the average value of happiness is and the more qualified a person is, the happier he/she is.

Significant differences can be shown between the subjective well-being of the population living in Nyíregyháza and in the nearest settlements regarding the levels of education, the labour market situation, social capital and the objective cultural capital.
\end{abstract}

Keywords: Measurement of well-being, Oxford Happiness Questionnaire, Subjective well-being 


\section{Bevezetés}

Amennyiben a Statisztikai Célú Területi Egységek Nómenklatúra ${ }^{38}$ területi szintjeit vesszük figyelembe, az mondható el, hogy Nyíregyháza az Észak-alföldi régióban helyezkedik el Szabolcs-Szatmár-Bereg megye megyeszékhelyeként és a Nyíregyházi járás székhelyeként.

A legtöbb mutató szerint az Észak-alföldi régió a kedvezőtlen helyzetü térségek közé tartozik, többek között azért, „,mert kevés a színvonalasabb szolgáltatást nyújtani képes kis-és középváros; magas viszont a fejletlenebb komfortszintü, elsősorban a szocializmus évtizedei alatt többé-kevésbé mesterségesen, korábbi falvakból létrehozott kisvárosok aránya,... s mert a rendszerváltást követően tönkrement nehézipari központok száma viszonylag nagy" (Kékesi 2007:72).

Az Észak-alföldi régió megyéi közül a legkedvezőtlenebb helyzetben SzabolcsSzatmár-Bereg megye van: a hátrányos helyzetü gyermekek aránya meghaladja a $60 \%$-ot, és ezen gyermekek felének szülei sem tanultak tovább az általános iskola befejezése után. A hazai átlagnál lényegesen alacsonyabb, 59\%-ot el nem érö aktivitási arány jellemzi, amelyhez alacsony foglalkoztatottsági szint is társul. Itt a legkevesebb a teljes munkaidőben alkalmazásban állók bruttó átlagkeresete és a családi adókedvezmény nélkül számított nettó átlagkeresetek nagysága (A Magyar Köztársaság Kormánya, 2007, Központi Statisztikai Hivatal, 2012).

Ugyanakkor, ha csak Nyíregyháza város adataira fókuszálunk, akkor azt tudjuk megállapítani, hogy e város „,szigetet jelent a szárazföldön”: 2012-ben a nyíregyházi háztartások egy főre jutó nettó jövedelmének átlaga az összes személyre számítva havi 74458 forint volt, amely a 2010-es vizsgálat átlagjövedelméhez (68 $000 \mathrm{Ft})$ képest mintegy 9,5\%-os nominális növekedést jelentett (Fábián - Takács - Szigeti, 2014). A növekedés hátterében vélhetően a 2012-es évre jellemző kedvezőbb foglalkoztatási helyzet állt, hiszen arra a kérdésre, hogy „Dolgozik-e Ön jelenleg?” a válaszadók 54,5 \%-a válaszolt igennel 2010-ben, 2012-ben már 57,2\% vallotta ugyanezt. A városban mért 2012. évi foglalkoztatási arány meghaladta az Északalföldi régió (47,9\%) és Szabolcs-Szatmár-Bereg megye (47,1\%) értékeit (Fábián Takács - Szigeti, 2014). Nyíregyháza lakosainak iskolázottsági színvonala is számottevően javult 2001 és 2011 között, ugyanis a „2011. évi népszámláláskor a város 25 éves és idősebb lakossága 27\%-ának volt felsőfokú végzettsége, ami az ország megyeszékhelyeit tekintve is kedvezö értékek közé tartozik" (Malakucziné, 2015 Acta Medicinae et Sociologica Vol. 6. No. 18-19: 11-29).

Jelen tanulmányunk témaválasztását leginkább az indokolta, hogy a „magyar nyelvü szakirodalomban meglehetősen kevés olyan anyag áll rendelkezésre" (Kékesi, 2007:72), amely az életminőség, valamint az életminőség szubjektív jóllét ${ }^{39}$ paraméterének vizsgálatával foglalkozik. Ezt az ürt igyekszünk enyhíteni oly módon, hogy eme szigeten, amelyet Nyíregyházának nevezünk, és a Nyíregyházi

\footnotetext{
${ }^{38}$ Nomenclature of Territorial Units for Statistics=NUTS

${ }^{39}$ A szubjektív jóllét/ az érzelmi jóllét nem más, mint a boldogság és az elégedettség tudományos megnevezése (Lelkes, 2003, Martos, 2009).
} 
járás egyéb településein ${ }^{40}$ élők körében megvalósítjuk az életminőség kutatás szubjektív jólléti tényezőjének feltárását az Oxfordi Boldogságmérő Kérdőív használatával, és kísérletet teszünk egy valós kép ábrázolására, amely a boldogság értékéről, illetve a boldogság összetevőire vonatkozó kijelentések megítéléséről szól.

\section{1. ábra: Nyíregyháza a Statisztikai Célú Területi Egységek Nómenklatúra területi}

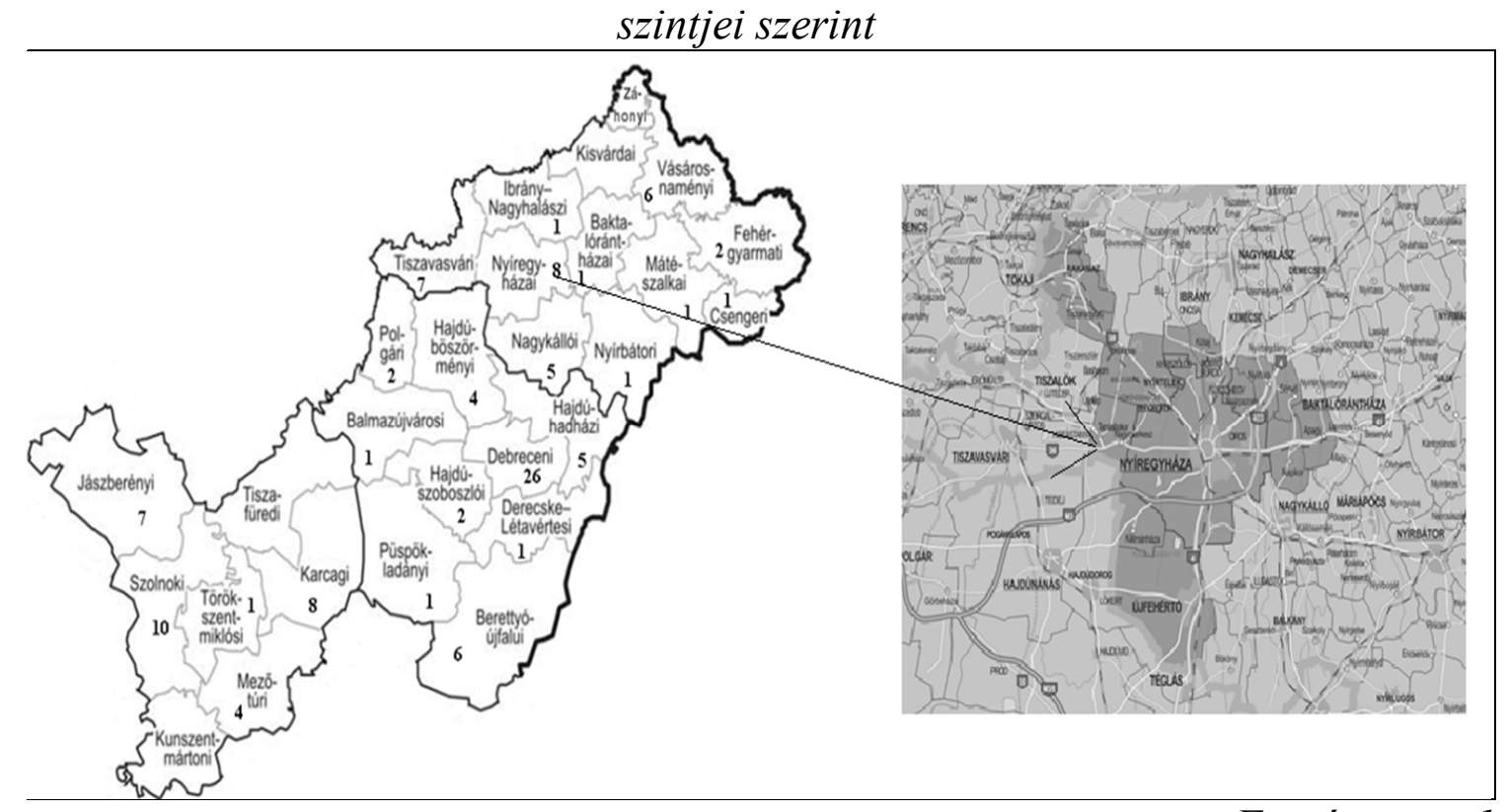

Forrás: www1

\section{Elméleti háttér}

Napjainkban egyre inkább hangsúlyossá válik az életminőség ${ }^{41}$ egyéni és társadalmi szintű vizsgálata, amely komplex módon csak az objektív tényezők és a szubjektív összetevők egyidejü mérésével valósítható meg (Ercsey, 2010). Ezt a tényt felismerve, 2008-ban a Nyíregyháza Megyei Jogú Város Polgármesteri Hivatal Szociális és Köznevelési Osztály munkatársai, valamint a Debreceni Egyetem Egészségügyi Kar Társadalomtudományi Tanszék dolgozói útjának indították az „Életminőség Nyíregyházán” címü kutatássorozatot, amely lehetőséget biztosít a Nyíregyházán élő, felnőtt városlakók életminőségének feltérképezésére és számszerüsítésére, valamint az adatfelvételek között eltelt időszak alatt

\footnotetext{
${ }^{40}$ A Nyíregyházi járás illetékes települései (Nyíregyháza nélkül), amelyet a kutatás további részében csak járásként, illetve járás egyéb településeiként emlegetünk: Apagy, Kálmánháza, Kótaj, Nagycserkesz, Napkor, Nyírpazony, Nyírtelek, Nyírtura, Rakamaz, Sényő, Szabolcs, Timár, Tiszanagyfalu, Újfehértó (www1).

${ }^{41}$ „Az életminőség az egyén észlelete az életben elfoglalt helyzetéről, ahogyan azt életterének kultúrája, értékrendszerei, valamint saját céljai, elvárásai, mintái és kapcsolatai befolyásolják. Szélesen értelmezett fogalom, amely bonyolult módon magába foglalja az egyén fizikai egészségét, pszichés állapotát, függetlenségének fokát, társadalmi kapcsolatait, személyes hitét, valamint a környezet lényeges jelenségeihez füződő viszonyát" (Egészségügyi Világszervezet, idézi Tróznai és Kullmann, 2003:30).
} 
megmutatkozó változások elemezésére, ismertetésére és magyarázatára (Fábián Patyán - Huszti, 2012).

A nyíregyházi életminőség kutatás a Rahman-modell elkötelezett híve (Rahman - Mittelhammer - Wandschneider, 2005). E modell nyolc részterületéből hetet sikerült lefedni a Háztartáspanel kérdőív kérdéseivel (2008-ban, 2010-ben, 2012ben), méghozzá a családi, baráti viszonyrendszerre; az egészségi állapotra; az anyagi jólétre; a lokális közösséghez tartozásra; a munkára és aktivitásra; a személyes biztonságra és a környezet minőségére vonatkozó paramétereket (Takács - Fábián, 2012). Az érzelmi jóllét mérése volt az, amely mindhárom adatfelvételi hullám során kimaradt, megfelelő mérőeszköz hiányában. Úgy gondoltuk, ezen összetevő vizsgálatát is feltétlenül meg kell valósítani az esedékes, 2015. évi adatfelvétel során, hisz' az élettel való elégedettség, a boldogság vizsgálata hihetetlen módon fejlödik az elmúlt évtizedtől fogva (Kopp - Skrabski, 2008), s melynek számszerüsítése és értelmezése napjainkra elengedhetetlenné vált. Ennek oka az a felismerés, hogy a társadalom életminőségéről csak akkor kapható teljes kép, ha a tárgyilagos és a perszonális mutatókat egymással kiegészítve használjuk (Ercsey, 2010). Ezt az álláspontot erősítette Berger-Smitt és Noll (2000) is, akik megállapították, hogy a társadalom fejlődésének célja nem a mindenáron való gazdasági növekedés, hanem az emberek jóllétének, életminőségének javítása. Rahman és munkatársai (2005) is ezt a nézetet vallották, amikor kidolgozták életminőség modelljüket, valamint Stiglitz, Sen és Fitoussi (2009) is, amikor elkészítették jelentésüket arról, milyen nagy szerepe van az életminőség alakításában a GDP-n túl a jóllétnek is. Mindezen nézőpontokat figyelembe véve megállapítottuk, olyan mérőeszközt szükséges keresnünk és találnunk, amely a boldogság, a boldogság több dimenziójának egyidejü vizsgálatára nyújt lehetőséget. Nemzetközi tanulmányokra (Hills - Argyle, 2002; Kashdan, 2004; Dogan - Totan - Sapmaz; 2013) és saját pilot vizsgálatokra hagyatkozva választásunk az Oxfordi Boldogságmérő Kérdőívre esett, amely a boldogságra, a boldogság alkotóelemeire, úgymint az önbecsülésre, a céltudatra, a társas érdeklődésre, a humorra vonatkozó állításokat tartalmazza (Hills - Argyle; 2002). A 6 fokú Likert-skála segítségével jelöli meg a válaszadó, hogy mennyire ért egyet vagy nem ért egyet az adott kijelentéssel.

\section{A kutatás ismertetése}

\section{A kutatás céljai és módszerei}

Empirikus vizsgálatunk egyik célja az volt, hogy az elégedettség értékét, mint perszonális jelzőszámot feltérképezzük mind Nyíregyháza városában, mind a járási településen élök körében: Meghatározza-e a szociokulturális háttér a boldogság értékét, illetve a boldogság összetevőire vonatkozó kijelentések megítélését?

Nemek szerint vizsgálódva az volt a hipotézisünk, hogy a férfiak és nők elégedettségi szintjei között nem fogunk jelentős eltérést tapasztalni (Molnár és Kapitány, 2013; Központi Statisztikai Hivatal, 2014), ugyanakkor az elvégzett osztályok számára és az életkorra fókuszálva már differenciára számítottunk: ezekre 
vonatkozóan a hipotéziseink azok voltak, hogy az iskolázottság mértékének növelése potenciálisan gyarapíthatja, az életkor emelkedése egy darabig csökkentheti, majd növelheti az elégedettség értékét (Lelkes, 2003; Kopp és Mészáros, 2012; Molnár és Kapitány, 2013; Komjáthy, 2014).

Ugyanakkor célkitüzésünk volt az is, hogy választ adjunk arra a kérdésre, hogy van-e lényeges, egyértelmü különbség a nyíregyházi városlakók és a járási településen élök szubjektív jóllét alakulásában, illetve annak legfontosabb feltételeiben.

Úgy véltük - a lakott település típusát figyelembe véve -, hogy a járási székhelyen élők jelentősen elégedettebbek azoknál, mint akik a járás egyéb településein élnek (Komjáthy, 2014).

Kutatásunk során kérdőíves módszert alkalmaztunk, kérdezőbiztosok bevonásával. A felmérés 2015. április elejétől június végéig tartott. A kiválasztottak a megkérdezés előtt levélből kaptak arról tájékoztatást, mikor és miért fogják őket felkeresni a kérdezőbiztosok. A minta kiválasztását - a megadott instrukciók alapján - a Közigazgatási és Elektronikus Közszolgáltatások Központi Hivatala végezte. A főmintából ,kiesett” vagy nem válaszolók helyettesítésére pótadatbázist, pótcímeket használtunk. A kitöltetett kartotékok feldolgozására, az eredmények kiértékelésére a varianciaanalízist, valamint a lineáris regressziós modellt használtuk 5\%-os valószínüségi szinten ( $p=0,05)$, amiben az SPSS 22.00 for Windows szoftver volt segítségünkre.

\section{A kutatás szociodemográfiai háttere}

Kutatásunkban a nyíregyháziakra és a Nyíregyházi járás egyéb településein lakókra koncentráltunk.

A nyíregyházi mintában a városlakók nemi megoszlása a következőképpen alakult: a válaszadók 46,4\%-a férfi, 53,6\%-a nő. Életkorcsoport szerint vizsgálódva a fiatalkorúak (18-25 év) 7,4\%-ban, a fiatal felnőttkorúak (26-34 év) 10,7\%-ban, a közép felnőttkor (35-49 év) 31,5\%-ban, az érett felnőttkorúak (50-64 év) 28,7\%-ban és az időskorúak (65 év felett) 21,7\%-ban képviseltetik magukat a mintában. Iskolai végzettség szerint alapfokú iskolai végzettséggel a megkérdezettek 31,9\%-a, középfokú iskolai végzettséggel 40,6\%, még felsőfokú iskolai végzettséggel 27,5\% rendelkezik.

A Nyíregyházi járási mintában a válaszadók 48,8\%-a férfi, 51,2\%-a nő. A fiatalkorúak aránya $11 \%$, a fiatal felnőttkorúaké $7,7 \%$, a közép felnőttkorúaké $30,3 \%$, az érett felnőttkorúaké 30,8\% és az időskorúaké 20,1\%. Az alapfokú iskolai végzettséggel rendelkezők tábora 59,7\%-ban, a középfokúaké 29,4\%-ban, a felsőfokúaké 10,9\%-ban van benne a kutatásban.

Ezek a szociodemográfiai ismérvek biztosítják jelen kötetben ismertetett vizsgálatok kiindulási alapjait. 
1. táblázat: A szociodemográfiai jellemzők százalékos megoszlása Nyíregyházán és a Nyíregyházi járásban

\begin{tabular}{|c|c|c|c|}
\hline \multirow{4}{*}{ Nem } & & Nyíregyháza & Nyíregyházi járás \\
\hline \multirow{4}{*}{ Korcsoport } & férfi (súlyozás után) & 46,4 & 48,8 \\
\cline { 2 - 4 } & nő (súlyozás után) & 53,6 & 51,2 \\
\cline { 2 - 4 } & fiatalkor & 7,4 & 11 \\
\cline { 2 - 4 } & fiatal felnőttkor & 10,7 & 7,7 \\
\cline { 2 - 4 } & közép felnőttkor & 31,5 & 30,3 \\
\cline { 2 - 4 } & érett felnőttkor & 28,7 & 30,8 \\
\cline { 2 - 4 } & időskor & 21,7 & 20,1 \\
\hline \multirow{3}{*}{ Iskolai végzettség } & alapfokú iskolai végzettség & 31,9 & 59,7 \\
\cline { 2 - 4 } & középfokú iskolai végzettség & 40,6 & 29,4 \\
\cline { 2 - 4 } & felsőfokú iskolai végzettség & 27,5 & 10,9 \\
\hline
\end{tabular}

Forrás: Nyíregyháza Életminösége 2015

\section{A kutatás eredményei}

Vizsgálatunk során górcső alá vettük a boldogságot kifejező szám értékét és alakulását, valamint a boldogság mérésére vonatkozó állitásokat és azok eloszlását, a különböző szociokulturális háttérrel rendelkezők körében.

Molnár és Kapitány a „szubjektív jóllétet meghatározó tényezök hatását magyar és osztrák háztartási szintü adatokon becsülve azonositották”, s megállapították, hogy a magyarországi férfiak és nők elégedettségi szintjei között nincs jelentős eltérés (Molnár és Kapitány, 2013:3). A Központi Statisztikai Hivatal (2014) elemzői ugyancsak azt állapították meg - a felnőtt férfiak és a felnőtt nők megoszlási értékeinek ismeretében -, hogy nincs jelentős különbség a két nem boldogságértéke között.

Az országos adatokhoz hasonlóan az érzelmi jóllétet jelző számot nem befolyásolja a megkérdezett személy neme, sem a Nyíregyházi járás székhelyén $(\mathrm{p}=0,342)$, sem a járás egyéb településein élők esetében $(\mathrm{p}=0,326)$. Ebböl az következik, hogy számottevő különbség nem létezik a férfiak és a nők 2015. évi emocionális szintje között. Ugyanakkor a Nyíregyházi járás székhelyén élö, „gyengébbik nem” képviselői szignifikánsan nagyobb arányban vallják magukról azt, hogy több érzést, azon belül is pozitív érzést táplálnak mások felé. Bevallásuk alapján nem érzik magukat igazán egészségesnek és a döntések meghozatalában is bizonytalanok. Érdekes, hogy a nyíregyházi férfiak és nők között nincs különbség a tekintetben, hogy mennyire találják vonzónak a külsejüket. 
2. táblázat: Az egyszempontos varianciaanalizishez tartozó leíró statisztikai eredmények Nyíregyházán, nemek szerint

\begin{tabular}{|c|c|c|c|c|c|}
\hline Nemek & Átlag & $\mathrm{N}$ & Szórás & Minimum & Maximum \\
\hline férfi & 4,19 & 264 &, 714 & 2 & 6 \\
\hline nö & 4,14 & 501 &, 708 & 1 & 6 \\
\hline Összesen & 4,16 & 765 &, 710 & 1 & 6 \\
\hline
\end{tabular}

ANOVA: $p=0,342(\mathrm{NS})^{42}$

Forrás: Nyíregyháza Életminősége 2015

A székhelyen kívül lakók közül a nők szintén arról számolnak be, hogy rájuk az asszertív attitüd, vagyis a mások iránti elfogadás és bizalom jellemző. Ök sem érzik saját egészségi állapotukat igazán helyénvalónak, megfelelőnek. A nyíregyháziakkal ellentétben ők már külsejükkel elégedetlenek, nem tartják azt elég vonzónak. A járási férfiak szignifikánsan nagyobb megoszlással számolnak be arról, hogy életük során bármit képesek elvállalni, nem létezik elöttük akadály.

3. táblázat: Az egyszempontos varianciaanalizishez tartozó leíró statisztikai eredmények járási szinten, nemek szerint

\begin{tabular}{|c|c|c|c|c|c|}
\hline Nemek & Átlag & $\mathrm{N}$ & Szórás & Minimum & Maximum \\
\hline férfi & 4,35 & 221 &, 682 & 2 & 6 \\
\hline nő & 4,29 & 354 &, 794 & 2 & 6 \\
\hline Összesen & 4,31 & 575 &, 753 & 2 & 6 \\
\hline
\end{tabular}

ANOVA: $p=0,326(\mathrm{NS})$

Forrás: Nyíregyháza Életminősége 2015

Az iskolai végzettség és az érzelmi állapot kapcsolatának vizsgálatát ismertető tanulmányok arról számolnak be, hogy „az iskolázottság összefügg az elégedettséggel: A magasabb képzettségüek átlagosan jobban meg vannak elégedve az életükkel (Lelkes, 2003:389, Kopp és Mészáros, 2012) és „a felsőfokú végzettségüek arányának növelése minden bizonnyal hozzájárulna a magyarok élettel való elégedettségének növeléséhez" (Molnár és Kapitány, 2013:23).

Ezekkel a kijelentésekkel egybecsengően megállapítottuk, hogy mind a Nyíregyházán élők, mind a járási településeken élők elégedettségi szintjére jelentős hatást gyakorol az edukáció $(\mathrm{p}=0,000)$.

Az iskolai végzettség szintjének a növekedésével jelentős mértékben növekedik a megyeszékhelyen élők boldogság értéke is: az alapfokú iskolai végzettséggel rendelkezők érzelmi jólléte 4,03, a középszintüeké 4,32, míg a felsőfokúaké 4,6. Az

${ }^{42}$ A *** jelöli a 0,001 alatti, a ** jelöli a 0,001 és a 0,01 közötti, a * jelöli a 0,01 és a 0,05 közötti szignifikanciákat. Az NS jelöli a nem szignifikáns, vagyis a 0,05-nél nagyobb értékeket. 
előbbi két csoport a kissé boldog, az utóbbi a nagyon boldog jelzőt, s kategóriát éri el.

A boldogság mérésére vonatkozó állítások vizsgálata során az rajzolódott ki, hogy az alapfokú végzettséggel rendelkezők pesszimisták, borúlátóak és kishitüek. Jellemző rájuk a fatalizmus: úgy gondolják, hogy nem azt teszik, amit igazán szeretnének. Úgy érzik, hogy a valóság és a vágyaik között óriási szakadék húzódik meg. Ezzel párhuzamosan az is megfigyelhető, hogy igazából nem rajtuk múlik, hogyan alakul életük, s igazából nincs is értelme és célja a létüknek, vagyis nem tartják valami jó helynek e világot. A külsejükkel és az egészségi állapotukkal sincsenek igazán megelégedve. Nehezen hoznak döntéseket és voltaképpen vidám emlékképekkel sem rendelkeznek.

A felsőfokú iskolai végzettséggel rendelkezők már sokkal derűlátóbbak és pozitívabbak. Racionálisak látják a jövőjüket, a lehetőségeiket, a döntési kompetenciájukat, valamint az önbecsülésük is jóval magasabb, mint az alacsonyabb végzettséggel rendelkezőkké. Képesek mások életére is hatást gyakorolni: azt mondják magukról, hogy pozitív érzéseket táplálnak mások felé, képesek másokat felvidítani, hisz' sokat nevetnek. Tele vannak energiával és szellemileg is meglehetősen ébernek érzik magukat.

1. táblázat: Az egyszempontos varianciaanalízishez tartozó leíró statisztikai eredmények Nyíregyházán, iskolai végzettség szerint

\begin{tabular}{|c|c|c|c|c|c|}
\hline Iskolai végzettség & Átlag & $\mathrm{N}$ & Szórás & Minimum & Maximum \\
\hline alapfokú & 4,03 & 169 &, 766 & 2 & 6 \\
\hline középfokú & 4,32 & 243 &, 755 & 2 & 6 \\
\hline felsőfokú & 4,60 & 153 &, 648 & 2 & 6 \\
\hline Összesen & 4,31 & 565 &, 760 & 2 & 6 \\
\hline
\end{tabular}

ANOVA: $\mathrm{p}=0,000(* * *$ szign. $)$

Forrás: Nyíregyháza Életminősége 2015

A járási településeken lakók esetében is igaz azon megállapítás, hogy a magasabb képzettségüek átlagosan jobban elégedettek az életükkel: A felsőfokú iskolai végzettséggel rendelkezők átlagos értéke 4,5, a középfokúaké 4,34, az alapfokúaké 4,01 .

A járási, többi településén élő, alapfokú végzettséggel rendelkezők körében még több pesszimista, fatalista kijelentés figyelhető meg, mint a nyíregyháziaknál. Ök is úgy gondolják, hogy nem azt teszik, amit igazán szeretnének, úgy érzik, hogy a valóság és a vágyaik között óriási szakadék húzódik meg. Szintén azt vallják, hogy igazából nem rajtuk múlik, hogyan alakul életük, s igazából nincs is értelme és célja a létüknek, nem tartják jó helynek a világot. Szintén elégedetlenek a külsejükkel és az egészségi állapotukkal. Nehezen hoznak döntéseket, és a vidám emlékképek birtoklásában sem jeleskednek. A nyíregyháziakhoz képest ők még azt is kijelentették, hogy nem szokták magukat jól érezni másokkal, nem tartják magukat igazán társasági lényeknek. 
A középfokú iskolai végzettséggel rendelkezők azok, akik a legtöbb dolgot szórakoztatónak tartják, akik sokat nevetnek, és képesnek érzik magukat arra, hogy másokat felvidítsanak.

A felsőfokú iskolai végzettséggel rendelkezők konzekvensen látják a lehetőségeiket, az életcéljukat. Képesnek érzik magukat arra, hogy bármit elvállaljanak, hisz’ szellemileg éberek és rengeteg energiával rendelkeznek.

5. táblázat: Az egyszempontos varianciaanalizishez tartozó leíró statisztikai eredmények járási szinten, iskolai végzettség szerint

\begin{tabular}{|c|c|c|c|c|c|}
\hline Iskolai végzettség & Átlag & $\mathrm{N}$ & Szórás & Minimum & Maximum \\
\hline alapfokú & 4,01 & 458 &, 713 & 1 & 6 \\
\hline középfokú & 4,34 & 218 &, 670 & 3 & 6 \\
\hline felsőfokú & 4,50 & 85 &, 584 & 3 & 6 \\
\hline Összesen & 4,16 & 761 &, 713 & 1 & 6 \\
\hline
\end{tabular}

ANOVA: $\mathrm{p}=0,000(* * *$ szign. $)$

Forrás: Nyíregyháza Életminősége 2015

Az életkor és a boldogság kapcsolatának vizsgálatával foglalkozó pszichológusok és közgazdászok szerint „a boldogság-életkor függvény egy U alakú görbe” (Bábás - Barta, 2013:26), vagyis a különböző korcsoportok boldogságértékei jelentős mértékben különböznek egymástól: A fiatalok és az idősek sokkal inkább elégedettek az életükkel, mint a középkorúak. Ezt az eredményt támasztja alá Molnár és Kapitány (2013:19) tanulmánya is, miszerint ,, az emberek 35-40 éves koruk táján a legkevésbé elégedettek az életükkel”, és ettől a ponttól kezdve az életkor előre haladtával a szubjektív jóllét állapota már nem romlik.

Ezekkel az országos adatokkal egybehangzóan a nyíregyházi és a járási településeken élők boldogságszintje is szignifikáns mértékben változik az életkor előre haladtával $(\mathrm{p}=0,000)$, de ezen adatok esetében nem egy U alakú görbe, hanem egy szigorúan monoton csökkenő, lineáris függvény írható le: minél idősebb egy korcsoport annál boldogtalanabb.

Nyíregyházán a fiatalkorúak átlagosan 4,59-os értékkel rendelkeznek, vagyis ők alkotják a nagyon boldog társadalmi kategóriát. A fiatal felnőtt korúak csoportja 4,47-os, a közép felnőtt korúak 4,44-os, az érett felnőttek 4,21-os, az időskorúak 4,09-os értéket produkálnak, amelyekkel már csak a kissé boldog csoportba sikerül bekerülniük.

A nyíregyházi fiatalkorúakra jellemző leginkább, hogy mások iránt érdeklődnek, és képesek másokat is felvidítani nevetésükkel. Úgy érzik, nagyon jó élni, és el tudnak bármilyen feladatot vállalni, nincsenek előttük akadályok. Szinte mindennel elégedettek, gyakran élnek át örömet, jókedvet, s tele vannak energiával. A közép felnőtt korúak csoportjától kezdve a negatív kicsengésú állítások sora figyelhető meg. A 35 és 49 év közötti korcsoport nem érzi magát jól e világban. Az 50-64 évesek egyáltalán nem elégedettek a külsejükkel. A 65 éven felüliek nem kimondottan bizakodóak a jövőjüket illetően, nem érzik magukat egészségesnek, 
nem szokták magukat már másokkal jól érezni. Ugyanakkor pozitív dolognak számít, hogy a nyugdíjas évek és az ezzel járó életstílus lehetővé teszi számukra, hogy mindenre tudjanak időt szakítani, amire csak akarnak.

2. ábra: Korcsoportok átlagos boldogságértéke, Nyíregyházán

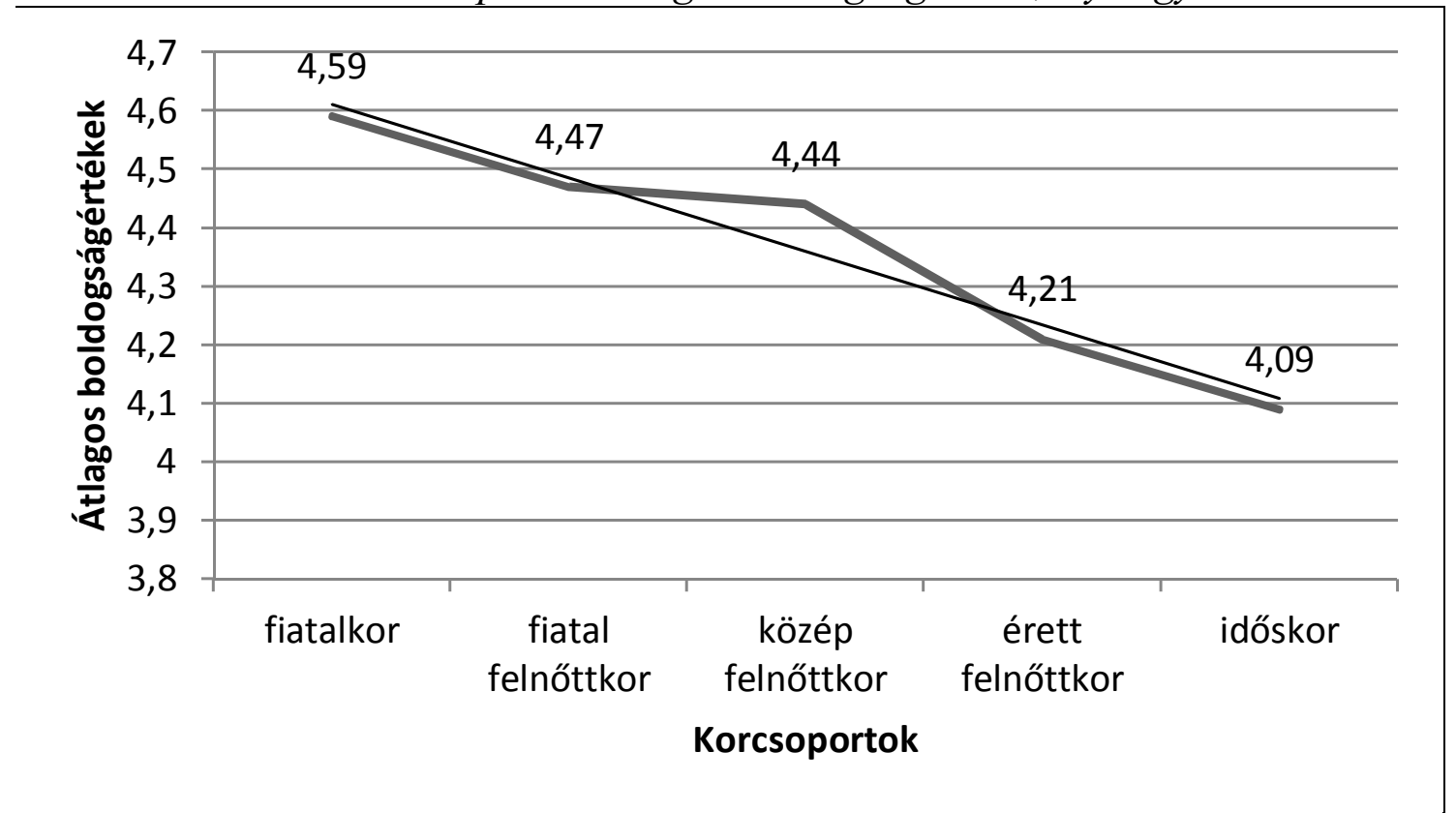

ANOVA: $\mathrm{p}=0,000(* * *$ szign. $)$

Forrás: Nyíregyháza Életminősége 2015

Járási szinten vizsgálódva szintén jelentős mértékben csökkennek a boldogságot jelző számok értékei: A fiatalkorúak átlagosan 4,51-os értékkel rendelkeznek, vagyis ők alkotják a nagyon boldog társadalmi kategóriát. A fiatal felnőtt korúak csoportja 4,44-os-, a közép felnőtt korúak 4,29-os-, az érett felnőttek 4,08-os-, az időskorúak 3,83-os értéket produkálnak, amelyekkel már csak a kissé boldog csoportba sikerül bekerülniük.

A fiatalkorúakra jellemző egyértelműen azon állítások többsége, amelyek pozitív töltetűek: úgy érzik, nagyon jó élni, és szinte mindennel elégedettek, amit életük során elértek. Sokat nevetnek, amellyel képesek felvidítani másokat is. Rátermettnek érzik magukat arra, hogy bármit elvállaljanak, hiszen mindenben megtalálják a szépségét, és igyekeznek is kedvezően befolyásolni a körülöttük lévő történéseket. Ennek következtében gyakran élnek át emelkedett érzéseket, örömöt. Szellemileg ébernek érzik magukat, rengeteg energiával bírnak.

A fiatal felnőttkorúak mindig nagyon belemerülnek abba, amit tesznek, és nagyon elkötelezetten teszik azt. Számukra szép az élet.

Az érett felnőttkorúak és az időskorúak a negatív végeredményü kijelentések birtokosai. Az érett felnőttkorúak nem örülnek saját maguknak, nem elégedettek önmagukkal. Az időskorúak koruknál fogva már nem kimondottan optimisták a jövőjüket illetően és nem is érzik magukat kimondottan egészségesnek. 
Egyértelműen már a külsejüket sem tartják elragadónak. Úgy érzik, nincs már igazán értelme és célja a létüknek, s valódi vidám emlékképekkel sem rendelkeznek.

3. ábra: Korcsoportok átlagos boldogságértéke, a járási településeken

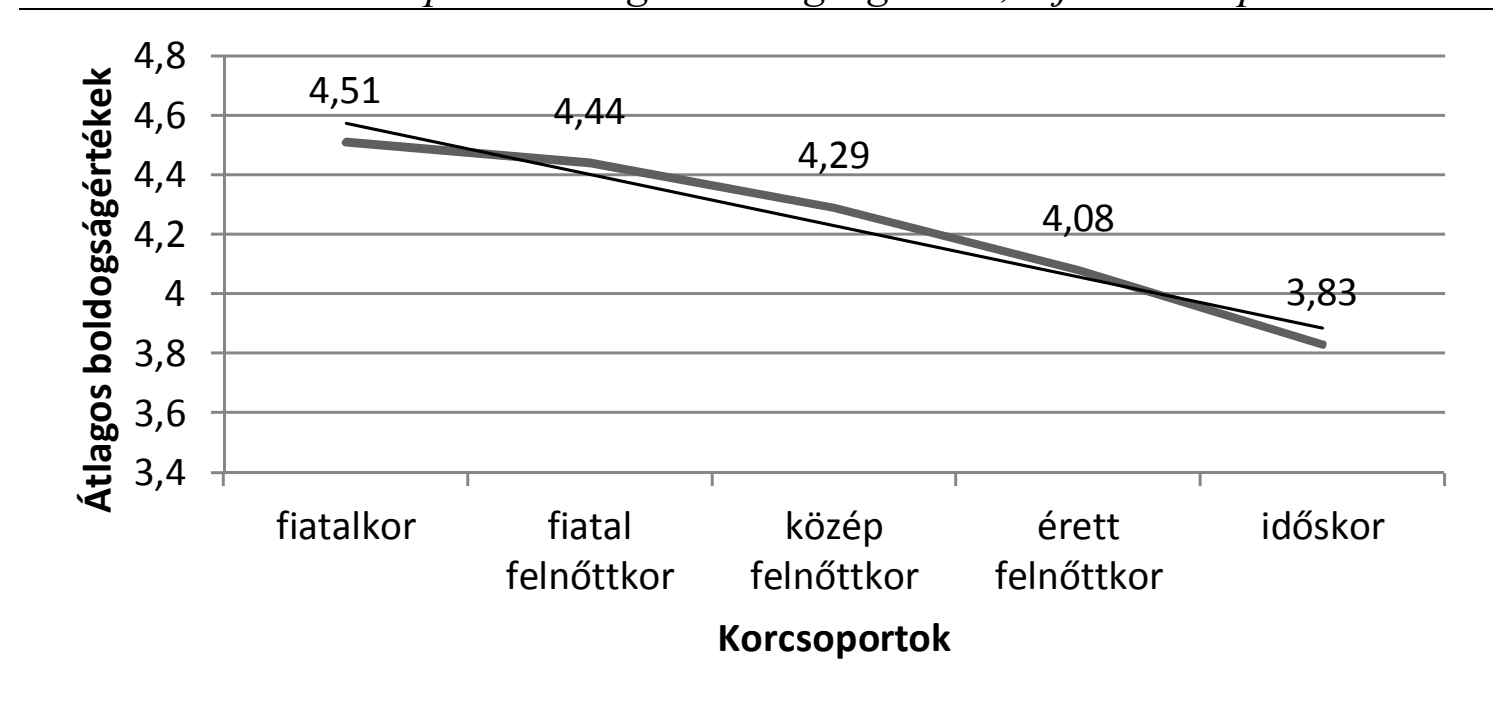

ANOVA: $\mathrm{p}=0,000(* * *$ szign. $)$

Forrás: Nyíregyháza Életminősége 2015

„A Gallup Intézet 2000-ben készitett felmérése szerint a hazai nagyvárosi (de nem fövárosi) lakosság körében a legmagasabb az élettel való általános elégedettség; a megyeszékhelyek, illetve a megyei jogú városok lakóinak 31 százaléka sorolta magát a nagyon elégedett, illetve az inkább elégedett kategóriák valamelyikébe. Sorrendben ezután a fövárosi lakosok, az egyéb városok (kisvárosok) polgárai, illetve a községekben élök következnek a felmérés eredményeinek tanúsága szerint" (Kékesi, 2007:73).

A 2005/2006-os Eurobarometer Magyarországra vonatkozó jelentésében az áll, hogy a leginkább elégedettnek a nagyvárosiak bizonyulnak. Öket a kisvárosiak, majd a falvakban élők követik (Kékesi, 2007).

Számunkra is az nyert tanúbizonyságot, hogy a járási székhelyen élők átlagos boldogságértéke nagymértékben különbözik a járási településen élők átlagos értékétől $(\mathrm{p}=0,00)$. Az előbbi csoport válaszadó tagjainak 86,7\%-a tartozik a kissé boldog, a nagyon boldog, valamint a túlságosan boldog kategóriába. Nem fordul elö egyetlen nem boldog polgár sem a kérdöívet kitöltő személyek között. A nem nyíregyházi lakosok elégedettségi szintje már ennél kisebb, 82,5\%-os értéket tudott elérni.

A jelentős mértékü eltérés oka a pozitív és negatív kimenetelü állítások előfordulásában figyelhető meg. A Nyíregyházán élőkre egyértelmủen az optimista, a derülátó, a bizakodó, a járási településen lakókra vitathatatlanul a passzív, a kishitü, a borúlátó kijelentések a jellemzők. A nyíregyháziak nagyon érdeklődők embertársaik iránt. A legtöbb dolgot szórakoztatónak tartják. Számukra szép az élet és zömmel elégedettek is vele. Amire akarnak, tudnak időt szakítani. Hatással vannak a saját döntéseikre, és általában azt pozitívan is befolyásolják. Velük 
ellentétben a járási településen élök nem optimisták, nem tartják vonzónak a külsejüket. Nem gondolják e világot jó helynek, és tulajdonképpen a világ dolgaival elégedetlenek, hiszen amit eddig tettek, azok nem azok, amit tenni is szerettek volna. Nehezen hoznak döntéseket, és a vidám emlékképek birtoklásában sem remekelnek.

6. táblázat: Az egyszempontos varianciaanalízishez tartozó leíró statisztikai eredmények Nyíregyházán és a Nyíregyházi járás egyéb településein

\begin{tabular}{|c|c|c|c|c|c|}
\hline & $\mathrm{N}$ & Átlag & Szórás & Minimum & Maximum \\
\hline Nyíregyháza & 581 & 4,31 & 0,756 & 2 & 6 \\
\hline Nyíregyházi járás & 768 & 4,16 & 0,71 & 1 & 6 \\
\hline
\end{tabular}

ANOVA: $\mathrm{p}=0,000(* * *$ szign. $)$

Forrás: Nyíregyháza Életminősége 2015

Ugyanakkor, ha a településeket külön-külön szemrevételezzük ${ }^{43}$, megállapítható, hogy a teljes Nyíregyházi járás átlagos boldogságértéke alatti $(4,22)$ értéket produkál Nyírtelek, Nagycserkesz, Rakamaz, Nyírpazony, Újfehértó és Kálmánháza.

Elszomorító továbbá az a tény is, hogy Nyírtelek, Rakamaz és Újfehértó településtípusát tekintve városok, és mégis a legrosszabb értékekkel rendelkeznek, valamint, hogy Nyíregyháza mint megyeszékhely, járási székhely nem a legmagasabb értékkel büszkélkedik.

\section{4. ábra: Település rangsor az áltagos boldogságértékek alapján}

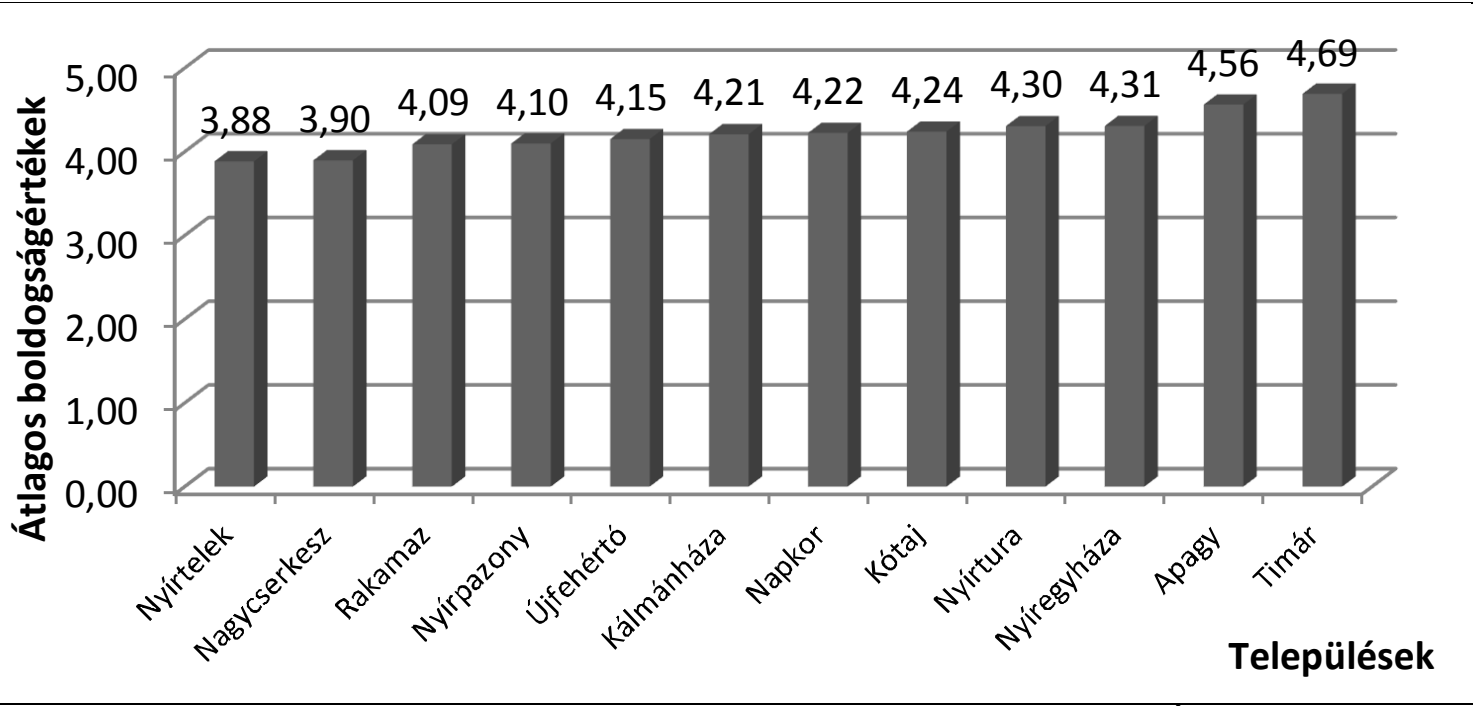

Forrás: Nyíregyháza Életminősége 2015

Tovább vizsgálódva a t-statisztika eredményeit, azt vettük észre, hogy a nyíregyháziak boldogságértékére vonatkozó magyarázatból leginkább két darab független változó veszi ki a részét, amelyeknek a hatásai szignifikánsak. Mind a kettő értelmező változó pozitív hatást gyakorol azon független változóra, amelyet úgy nevezünk, hogy elégedettség. Értékét Nyíregyházán leginkább a munkaviszony, a munkahely megléte $(\beta=0,428)$ befolyásolja, majd a barátokkal való rendelkezés

${ }^{43}$ Az elemzés jelenlegi szakaszában Sényőt ki kellett zárnunk az alacsony elemszáma miatt. 
$(\beta=0,425)$ : az elégedettség szintje nagymértékben magasabb azoknál, akik munkahellyel és/vagy baráti kapcsolatokkal rendelkeznek, mint akik egyik változó birtoklásában sem jeleskednek. Érdekes megállapítás azonban az, hogy a háztartások tagjainak munkaerö-piaci helyzete nem mutat szoros összefüggést a jövedelemmel.

2. táblázat: Lineáris regressziós eredmények a nyíregyháziak boldogságértékére vonatkozóan

\begin{tabular}{|c|c|c|c|c|c|}
\hline \multirow{2}{*}{ Magyarázó változók } & \multicolumn{2}{|c|}{$\begin{array}{c}\text { Nem standardizált } \\
\text { koefficiensek }\end{array}$} & $\begin{array}{c}\text { Standardizált } \\
\text { koefficiensek }\end{array}$ & \multirow{2}{*}{$\mathrm{t}$} & \multirow{2}{*}{ Szign. } \\
\cline { 2 - 5 } & $\mathrm{B}$ & Std. Hiba & Béta & & \\
\hline Konstans & 3,817 &, 827 & & 4,616 &, 000 \\
\hline $\begin{array}{c}\text { Egy före jutó nettó } \\
\text { jövedelem }\end{array}$ & $7,345 \mathrm{E}-07$ &, 000 &, 035 &, 234 &, 816 \\
\hline Dolgozik-e? &, 679 &, 267 &, 428 & 2,545 &, $015^{*}$ \\
\hline Van-e barátja? &, 683 &, 258 &, 425 & 2,641 &, $012^{*}$ \\
\hline $\begin{array}{c}\text { Kulturális fogyasztás } \\
\text { fökomponens }\end{array}$ &,- 001 &, 183 &,- 001 &,- 004 &, 997 \\
\hline $\begin{array}{c}\text { Objektivált kulturális töke } \\
\text { fókomponens }\end{array}$ &, 197 &, 137 &, 257 & 1,438 &, 159 \\
\hline Olvas-e? &, 130 &, 327 &, 073 &, 398 &, 693 \\
\hline Objektív anyagi töke index &, 028 &, 032 &, 137 &, 851 &, 400 \\
\hline
\end{tabular}

$\mathrm{Az} \mathrm{R}$ értéke=0,563, az $\mathrm{R}^{2}$ értéke=0,317, az AdjR négyzet értéke=0,184.

Forrás: Nyíregyháza Életminősége 2015

A logisztikus regressziós modell alapján a járási településen élők körében is az figyelhető meg, hogy a hét darab bevont magyarázó változóból kettő gyakorol hatást az elégedettség szintjére. Az objektivált kulturális tőke főkomponens és az állással való rendelkezés befolyásolja szignifikánsan a boldogság értékét: A legnagyobb hatást a tárgyiasult kulturális tőke fökomponens $(\beta=0,509)$ fejti ki, majd a munkahellyel való rendelkezés $(\beta=0,271)$. Mindkettő változó pozitív irányban befolyásolja a jóllét alakulását: minél több objektivált kulturális tőkével rendelkezik az adott egyén, annál magasabb a boldogságra vonatkozó értéke, illetve minél kedvezőbb munkaerő-piaci helyzetben van a megkérdezett felnőtt városlakó annál elégedettebb.

\footnotetext{
${ }^{44}$ A múzeumban, a könyvtárban, a színházban, a fesztiválon és a koncerten való megjelenések összessége.

${ }^{45}$ A kulturális tőke azon megjelenési formája, amely materiálisan megfogható, átadható, sokszorosítható és eladható (könyv, lexikon, szótár, idegen nyelvi könyv, művészeti album).
} 
3. táblázat: Lineáris regressziós eredmények a járási településen lakók boldogságértékére vonatkozóan

\begin{tabular}{|c|c|c|c|c|c|}
\hline \multirow[t]{2}{*}{ Magyarázó változók } & \multicolumn{2}{|c|}{$\begin{array}{l}\text { Nem standardizált } \\
\text { koefficiensek }\end{array}$} & \multirow{2}{*}{\begin{tabular}{|c}
$\begin{array}{c}\text { Standardizált } \\
\text { koefficiensek }\end{array}$ \\
Béta
\end{tabular}} & \multirow[t]{2}{*}{$\mathrm{t}$} & \multirow[t]{2}{*}{ Szign. } \\
\hline & B & Std. Hiba & & & \\
\hline Konstans & 4,230 & ,464 & & 9,123 &, 000 \\
\hline Egy före jutó nettó jövedelem & $3,771 \mathrm{E}-07$ &, 000 &, 016 & , 136 & ,892 \\
\hline Olvas-e? &,- 211 &, 165 &,- 144 & $-1,280$ & ,206 \\
\hline Van-e barátja? &, 057 &, 154 &, 042 &, 370 &, 713 \\
\hline Dolgozik-e? &,- 373 &, 176 &,- 271 & 2,119 &, $039 *$ \\
\hline $\begin{array}{l}\text { Kulturális fogyasztás } \\
\text { fókomponens }\end{array}$ &, 054 & , 100 & ,066 &, 545 &, 588 \\
\hline Objektív anyagi tőke index &,- 006 & 017 &,- 043 &,- 328 &, 744 \\
\hline $\begin{array}{l}\text { Objektivált kulturális töke } \\
\text { fökomponens }\end{array}$ & ,376 &, 112 &, 509 & 3,350 &, $002 * *$ \\
\hline
\end{tabular}

$\mathrm{Az} \mathrm{R}$ értéke=0,676, az $\mathrm{R}^{2}$ értéke=0,457, az AdjR négyzet értéke=0,383.

Forrás: Nyíregyháza Életminősége 2015

\section{Összegzés}

Kutatásunk során sikerült feltérképeznünk a boldogság értékét, valamint a boldogság összetevőire vonatkozó kijelentések megítélését mind a Nyíregyházi járás székhelyén, mind a Nyíregyházi járás egyéb településein élök körében.

A vizsgálat konzekvenciájaként az mondható el, hogy a boldogságértékek alakulásában rétegspecifikus jellemvonások uralkodnak mindkét vizsgálati populációban.

Szignifikáns különbség létezik az életkorcsoportok boldogságértékei között, vagyis minél idősebb egy korcsoport annál kisebb a boldogság átlagos értéke. Az elvégzett osztályok száma ugyancsak hatást gyakorol az elégedettségre. A magasabb végzettségüek csoportja átlagosan boldogabb, mint az alacsonyabb kvalifikációval rendelkezőké.

A vizsgálat eredményeként megállapítható az is, hogy lényeges, kardinális különbség létezik a nyíregyházi városlakók és a járás egyéb településein élők szubjektív jóllét alakulásában, illetve annak legfontosabb feltételeiben. Ennek oka a pozitív és negatív kimenetelü állítások előfordulásában figyelhető meg. A Nyíregyházán élőkre egyértelmüen az optimista, a derülátó, a bizakodó, a járási településen lakókra vitathatatlanul a passzív, a kishitü, a borúlátó kijelentések a jellemzök. 
A boldogság értékét Nyíregyházán leginkább a munkaerő-piaci helyzet és a baráti kapcsolatok megléte befolyásolja.

Az elégedettség szintje nagymértékben magasabb azoknál, akik munkahellyel rendelkeznek, de nem magasabb azoknál, akik több jövedelemmel is rendelkeznek. Ebböl az következik, hogy elsősorban nem a megélhetési javak, a jövedelem megszerzése miatt elégedettebbek azok, akik foglalkoztattak. A megelégedés hátterében sokkal inkább állhat a csapathoz tartozás érzése, a kollegiális viszony megléte, az önmegvalósítás, a karrier út kiépítése, stb.

Ugyanakkor az elégedettség szintje azoknál is magasabb, akik baráti kapcsolatokkal, kapcsolathálózattal rendelkeznek.

A járási településen élők boldogság szintjét az objektivált kulturális tőke főkomponens és a kedvező munkaerő-piaci helyzet instruálja szignifikánsan: a minél több és több objektivált kulturális tőkével való rendelkezés növeli az elégedettség szintjét. A munkahellyel rendelkezők tábora - akárcsak a Nyírség fövárosában élők esetében - jelentősen magasabb boldogságértéket ér el azoknál, mint akik nem foglalkoztatottak.

Összességében a felsőfokú végzettségüek arányának növelése, a munkaerő-piaci helyzet és a kapcsolathálózat javítása, a személyes hálózatok kiépítése, a különböző klubokhoz, szervezetekhez való hovatartozás megteremtése, valamint a tárgyiasult kulturális tőkével való rendelkezés fokozása és megfelelő szinten történő hasznosítása minden bizonnyal hozzájárulna a Nyíregyházi járás településein élők boldogságszintjének növeléséhez.

\section{Irodalomjegyzék}

1. A Magyar Köztársaság Kormánya (2007): Észak-alföldi operatív program 20072013.

http://www.eszakalfold.hu/userfiles/hun/fejlesztesi_dokumentumok/eAOP/EAOP adopted hu.pdf. Utolsó látogatás: 2015. 09. 16.

2. Berger-Smitt R. - Noll H. H. (2000) Conceptual framework and Structure of a European System of Social Indicators. EU Reporting Working Paper, No. 9, ZUMA, Mannheim.http://www.gesis.org/fileadmin/upload/institut/wiss_arbeitsbereiche/so z_indikatoren/Publikationen/paper9_1_pdf. Utolsó látogatás: 2015. 10. 10.

3. Bábás Csilla Enikő - Barta Evelyn (2013): A boldogság tudományos útjain. OTDK dolgozat.

4. Dogan T. - Totan T. - Sapmaz F. (2013): The role of selfe-esteem psychological well-being, emotional self-efficacy and affect balance on happiness: a path model. European Scientific Journal Vol 9, No 20. pp. 31-42.

5. Ercsey Ida (2010): Az életminőség mérése. In.: Losoncz Miklós - Szigeti Cecília (szerk.) (2010): Válság közben, fellendülés elött. Széchenyi István Egyetem Kautz Gyula Gazdaságtudományi Kar, Győr.

6. Fábián Gergely - Patyán László - Huszti Éva (2012): Előszó. In.: Huszti Éva Patyán László - Fábián Gergely (szerk.) (2012): Életminőség Nyíregyházán, 20082010. Acta Medicinae et Sociologica. Debreceni Egyetem Egészségügyi Kar, Nyíregyháza. 5-10. oldal

7. Fábián Gergely - Takács Péter - Szigeti Fruzsina (2014): A jövedelmi helyzet változása, a társadalmi polarizálódás jellemzői Nyíregyháza városában. In.: Huszti 
Éva - Patyán László - Fábián Gergely (szerk.) (2014): Életminőség Nyíregyházán, 2012. Acta Medicinae et Sociologica Vol. 5. No. 12-13. Debreceni Egyetem Egészségügyi Kar, Nyíregyháza. 47-59. oldal.

8. Hills P. - Argyle M. (2002): The Oxford Happiness Questionnaire: a compact scale for the measurement of psychological well-being. Personality and Individual Differences 33.: pp. 1073-1082.

9. Kashdan T. B. (2004): The assessment of subjective well-being (issues raised by the Oxford Happiness Questionnaire). Personality and Individual Differences 36, pp. $1225-1232$

10. Kékesi Márk Zoltán (2007): A szubjektív életminőség térbeli vonatkozásai. In: Utasi Ágnes (szerk.) (2007): Az életminöség feltételei. Mühelytanulmányok. MTA Poltitikai Tudományok Intézete: 72-83. oldal.

11. Komjáthy Dénes (2014): A szubjektív jóllét vizsgálata Budapest V. és XIX. kerületének példáján. Földrajzi Közlemények 138. évfolyam, 4. szám. 322-333. oldal.

12. Kopp Mária - Skrabski Árpád (2008): Miért alapvető politikai fogalom a társadalom boldogság érzete? Valóság 2. évfolyam, 30-38. oldal.

13. Központi Statisztikai Hivatal (2012): Magyarország társadalmi atlasza. Xerox Magyarország Kft., Budapest.

http://www.ksh.hu/docs/hun/xftp/idoszaki/pdf/tarsatlasz.pdf. Utolsó látogatás: 2015. 09. 16.

14. Központi Statisztikai Hivatal (2014): A jólléti Magyarország indikátorrendszere, 2013. Xerox Magyarország Kft., Budapest.

15. Lelkes Orsolya (2003): A pénz boldogít? A jövedelem és a hasznosság kapcsolatának empirikus elemzése. Közgazdasági Szemle 50. évfolyam, 383-405. oldal. http://epa.oszk.hu/00000/00017/00093/pdf/lelkes.pdf. Utolsó látogatás: 2015. 08. 25.

16. Malakucziné Póka Mária (2015): A Nyíregyházi járás települési szerkezeti, demográfiai, háztartási jellemzői. In.: Huszti Éva - Patyán László - Fábián Gergely (szerk.) (2015): Életminöség Nyíregyházán, 2015. Acta Medicinae et Sociologica Vol. 6. No. 18-19. Debreceni Egyetem Egészségügyi Kar, Nyíregyháza, 11-29. oldal.

17. Martos Tamás (2009): Célok, tervek, törekvések I. Elméleti megfontolások és alkalmazási lehetőségek. Magyar Pszichológiai Szemle 2. évfolyam, 337-358. oldal.

18. Molnár György - Kapitány Zsuzsa (2013): Miért elégedetlenek annyira a magyarok az életükkel? A szubjektív jóllétet befolyásoló tényezők mikroszintű összehasonlító elemzése magyar és osztrák adatokon. Műhelytanulmányok. MTA Közgazdaság és Regionális Tudományi Kutatóközpont, Közgazdaság Tudományintézet, Budapest. http://econ.core.hu/file/download/mtdp/MTDP1347.pdf. Utolsó látogatás: 2015. 09.16.

19. Rahman T. - Mittelhammer R. C. - Wandschneider P. (2005): Measuring the Quality of Life across Countries. Research Paper No. 06.

20. Stiglitz J. E. - Sen A. - Fitoussi J. P. (2009): Report by the Commission on the Measurement of Economic Performance and Social Progress. http://www.stiglitzsen-fitoussi.fr/documents/rapport_anglais.pdf. Utolsó látogatás: 2015. 09. 16.

21. Takács Péter - Fábián Gergely (2012): Egy lokális életminőség index kialakításának lépései. In: Fábián Gergely - Patyán László - Huszti Éva (szerk.) (2012): Életminöség Nyíregyházán, 2008-2010. Debreceni Egyetem Egészségügyi Kar, Nyíregyháza: 49-69. oldal. 
22. Tróznai Tibor - Kullmann Lajos (2003): A WHOQOL-100 életminőség-vizsgáló kérdőív magyar verziójának validálása. Rehabilitáció 16. évfolyam, 2. szám, 28-36. oldal.

23. www1: jaras.info.hu/jarasok-terkepe/jarasok-szabolcs-szatmar-bereg-megyeben. Utolsó látogatás: 2015. 09. 15.

\section{Szerzők}

Szigeti Fruzsina okleveles egészségpolitikai szakértő, PhD. hallgató, szigeti.fruzsina.89@gmail.com

Debreceni Egyetem Bölcsészettudományi Kar Nevelés- és Müvelődéstudományi Doktori Program, 4032 Debrecen, Egyetem tér 1.

Fábián Gergely PhD. szociológus, kutató, föiskolai tanár, fabian.gergely@foh.unideb.hu Debreceni Egyetem Egészségügyi Kar, 4400 Nyíregyháza, Sóstói u. 2-4.

Takács Péter PhD. statisztikus, föiskolai docens, takacs.peter@foh.unideb.hu Debreceni Egyetem Egészségügyi Kar, 4400 Nyíregyháza, Sóstói u. 2-4. 